\title{
Viscoelastic Behavior and Sensory Evaluation of Thickening Sol-Style Foods Prepared with the Use of Thickening Agents Made of Mixed Starch-Guar Gum
}

\author{
Tomoko TAKAHASHI $^{* 1}$, Aki KAWANO ${ }^{* 2}$, and Hiro OGOSHI ${ }^{* 2}$ \\ ${ }^{{ }^{*}}$ Faculty of Human Life, Jumonji University, Niiza, Saitama 352-8510, Japan \\ ${ }^{* 2}$ Faculty of Home Economics, Japan Women's University, Bunkyo-ku, Tokyo 112-8681, Japan
}

\begin{abstract}
Consistent thickening sol-style food samples having hardness equivalent to salad oil and plain yoghurt, respectively, were prepared with the use of thickening agents made of mixing starch and guar gum in various composition ratios. The correlation between the viscoelastic behavior of these samples and such sensory values as "ease of swallowing" was studied. An effective way of assessing the "in-mouth sensation" and "ease of swallowing" of these consistent sol-style food samples was to examine the $\tan \delta$ of the dynamic viscoelasticity of the sample in the linear region, as well as the distortion dependence and, in particular, to study the torque and attenuation status of $G^{\prime}$ in the non-linear region. The "ease of swallowing" of the samples can be estimated to a certain extent from the $G^{\prime}$ and $\tan \delta$ on the low frequency side.
\end{abstract}

Key Words: Mixed starch-guar gum thickening agent / Dynamic viscoelasticity / Sensory evaluation / Strain dependence / Frequency dependence

\section{デンプン - グアーガム混合系増粘剤により調製した粘稠ゾル状食品の 粘弾性挙動と官能評価}

\author{
高橋 智子 ${ }^{* 1}$, 川野 亜紀 ${ }^{* 2}$, 大越 ひろ*2
}

(原稿受理 : 2004年12月13日)

\begin{abstract}
1. 緒言

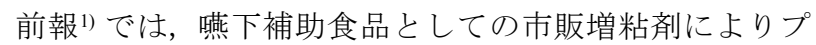
レーンヨーグルト程度の硬さの粘稠な液状食品を調製し, そ の粘弾性挙動と健常な人の飲み込みや寸さなどの官能評価 との関係を検討した. その結果, 市販増粘剤の粘稠性発現物 質がデンプン，グアーガムあるいはグアーガムとデンプンの 混合物かにより, 粘弾性挙動および官能評価が大きく異なる ことが示された. しかし，グアーガムとデンプンの混合割合 とその粘弾性挙動の変化, およびその粘弾性挙動の変化と官 能評価の関係について, 前報1)では明確にできなかった。 そ こで, 本研究では, デンプンとグアーガムの混合割合を変え た5種類の増粘剤を調製し, 前報 ${ }^{1)}$ にき続きプレーンヨーグ ルト程度の硬さを有する粘稠な液状食品の粘弾性挙動と官 能評価との関係について検討した. また, 市販介護食品でた れやソースに利用されている液状食品の硬さは, サラダ油程 度からプレーンヨーグルト程度であることが多い，そこで， プレーンヨーグルト程度の硬さに加え, 本研究では, サラダ
\end{abstract}

1 十文字学園女子大学人間生活学部

于 352-8510 新座市菅沢 2-1-28

"2 日本女子大学家政学部

厂 112-8681 文京区目白台 2-8-1
油程度の硬さに調製した粘稠な液状食品についても検討を 加えた。これらの関係を検討することにより, 健常な人の口 中感覚, および飲み込みやすさを把握することができる粘弾 性を，より詳細に知ることができると考える，さらには，本 研究より得られた結果が曣下に障害がある人にとって, 安全 に食べることができる液状食品の開発の基礎的データーに なると考える. 若干の知見が得られたので, ここに報告する.

\section{2. 実 験}

\section{1 試料}

増粘剤として，ワキシーコーンスターチ由来の $\alpha$ 化デンプ ン（松谷化学工業株式会社 : 以後デンプンと呼ぶ）およびグ アーガム（三栄源エフ・エフ・アイ株式会社）の配合割合を 変えて混合した増粘剤を蒝留水に添加し, サラダ油状および プレーンヨーグルト状の2段階の硬さに調製したものを試料 とした. すなわち，サラダ油状の硬さにデンプン単独で調製 する場合, その濃度は $3.30 \%(\mathrm{w} / \mathrm{v})$ であり, この試料を OS-G(1:0) の略号で示すことにする．またグアーガム単独で調製する場 合，その濃度は $1.10 \%(\mathrm{w} / \mathrm{v})$ であり，この試料を OS-G(0:1)の略 号で示すことにする。このデンプンおよびグーガムの濃度を 両端とし，デンプンとグアーガムの配合割合を等間隔に5段 
階に設定し，混合系試料を調製した。 また，プレーンヨーグ ルト状の硬さにデンプン単独で調製する場合の濃度は $6.20 \%(\mathrm{w} / \mathrm{v})$ であり，この試料をYS-G(1:0)の略号で示した.グ アーガムのみで調製する場合の濃度は $2.00 \%(\mathrm{w} / \mathrm{v})$ であり，こ の試料をYS-G(0:1)の略号で示すことにした. サラダ油状と同 様にプレーンヨーグルト状においても，5段階のデンプンと グアーガムの配合割合を設定し, 試料とした。 サラダ油状の 硬さおよびヨーグルト状の硬さにおける試料の略号, 配合割 合, デンプンおよびグーガムの添加濃度を Table Iに示した. サラダ油状およびプレンヨーグルト状共に, 前報 ${ }^{2)}$ に従い試 料調製を行った. 寸なわち, 定量のデンプンおよびグアーガ ムを計量後, それらを単独あるいは混合し, $20^{\circ} \mathrm{C}$ の蒸留水一 添加する. 手動により 60 回／分の速度で 1 分間攪找し, 後 30 分間放置したものを試料とした. 各試料のテクスチャー特性 值（硬さ，付着エネルギー，凝集性）をTable Iに示した。テ クスチャー特性はレオナー（高分解能型レオナーModel RE33005 : 山電 (株)）により得られた時間-荷重曲線より算 出した. 測定は, 直径 $20 \mathrm{~mm}$, 透明合成樹脂製のプランジャー を用い, 圧縮速度 $10 \mathrm{~mm} / \mathrm{sec}$ の定速圧縮法により, 試料はひず み $67 \%$ で行った。 この測定方法は, 厚生省により通達された 嚥下障害者のためのゾル状食品の硬さの測定法に従ったも のである. 3)

\section{2 動的粘弾性測定}

動的粘弾性特性は, 100FRT-N1(Rheometric Far East

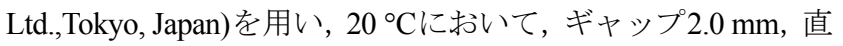
径 $50 \mathrm{~mm}$ の平行板治具により測定した。ひずみ依存測定は角 周波数 $\omega=10 \mathrm{rad} / \mathrm{sec}$ で行い, 測定ひずみ範囲は0.01 100\%であ る.また, 周波数依存測定は, いずれの試料も線形性を示す ひずみ量であるひずみ $0.2 \%$ で行い, 角周波数 $0.1 \sim 100 \mathrm{rad} / \mathrm{sec}$ の 範囲で測定した。

\section{3 官能評価}

官能評価はシェッフェの一対比較法を用い，個室法により 行った. パネルは, 訓練された本学食物学科学生のべ 60 名で ある. 評価時の試料一口量は, $10 \mathrm{ml}$ 定量スプーンにより供食

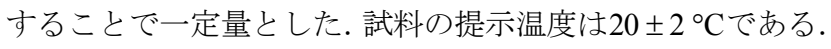
評価項目, および順序は, 口中のべたつき感 $(-3$ : 非常に少 ない $\rightarrow+3:$ 非常に多い), 口中の残留感 $(-3:$ 非常に少な

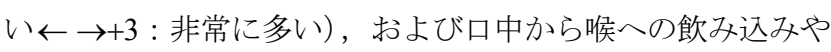
すさ $(-3:$ 非常に飲み込みにくいた $\rightarrow+3$ : 非常に飲み込みや すい) の3項目である.

\section{3. 結果および考察}

\section{1 ひずみ依存性}

Fig. 1にサラダ油状試料, およびFig. 2にヨーグルト状試料の 周波数 $10 \mathrm{rad} / \mathrm{sec}$ における $G^{\prime}$, トルク $T_{\mathrm{r}}$ および $\tan \delta$ のひずみ依 存測定の結果を示した。線形領域における $G^{\prime}$ は, サラダ油 状試料，およびヨーグルト状試料において，いずれもデン プン単独試料であるS-G(1:0)が最も高いことは共通している. サラダ油状試料では, OS-G(1:0)に続いて, G'はOS-G(0:1), OS-G(0.25:0.75)の順に小さくなった. また, OS-G(0.5:0.5) と OS-G(0.75:0.25)の $G^{\prime}$ はほぼ同值を示し, 試料の中では最も小さ いものとなったが，グアーガムを含む試料の線形領域におけ る $G^{\prime}$ 值の差は小さい. 一方, ヨーグルト状試料の $G^{\prime}$ は, デン プン単独試料YS-G(1:0)に続いて, YS-G(0: 75:0.25), YS-G(0.5:0.5), YS-G(0.25:0.75)の $G^{\prime}$ はほぼ同程度の值で, 小さい。また, YS-G(0:1)の $G^{\prime}$ は最も小さいものとなったが，比較的グアーガ ムを含む試料の線形領域における $G^{\prime}$ はいずれも等しい.

サラダ油状試料，およびヨーグルト状試料いずれも，線形 性の範囲を超えると, それ以上の変形ではトルクが減衰し, また $G^{\prime}$ も減少する非線形領域を示した. サラダ油状試料で最 も線形領域が狭く（線形領域 $0.2 \%$ 以下），非線形領域におけ るトルクの減衰, およびG'の減少が顕著なものは, OS-G(1:0) であり，5種類の試料の中で，ひずみ依存性は最も大である. 続いて, OS-G(0.75:0.25), OS-G(0.5:0.5)の順にひずみ依存性は小 さくなっていることが, Fig. 1よりわかる. また, OS-G(0.5:0.5), OS-G(0.25:0.75), およびOS-G(0:1)のひずみ依存性は, 他の 2 試 料に比べ小さい.この3種の試料間におけるひずみ依存性の 差は小さいが，その中でも OS-G(0:1)の線形領域はひずみ $10 \%$ 以下と広く，ひずみ依存性が最も小さい.

一方，ヨーグルト状の硬さにおける試料においても, YS-G(1:0)の線形領域はひずみ $1 \%$ 以下を示し, また非線形領域 におけるトルクの減衰, および $G^{\prime} の$ 減少が最も大である. 続いて, YS-G(0.75:0.25), YS-G(0.5:0.5)の順にひずみ依存 性は小さくなっている。 また，グアーガムの配合割合が多い YS-G(0.25:0.75), YS-G(0:1)の線形領域は共にひずみ $10 \%$ 以下

Table I Volume fraction of the mixed sol samples.

\begin{tabular}{|c|c|c|c|c|c|c|c|}
\hline \multicolumn{8}{|c|}{ Salad oil style samples } \\
\hline \multirow[t]{2}{*}{ Abbreviation } & \multicolumn{2}{|c|}{ Volume fraction } & \multicolumn{2}{|c|}{ Conc. $(w / v \%)$} & \multirow{2}{*}{$\begin{array}{l}\text { Hardness } \\
\times 10^{2} \mathrm{~N} / \mathrm{m}^{2}\end{array}$} & \multirow{2}{*}{\multicolumn{2}{|c|}{$\begin{array}{l}\text { Adhesiveness Cohesiveness } \\
\times 10 \mathrm{~J} / \mathrm{m}^{3}\end{array}$}} \\
\hline & Starch & : Guar gum & Starch & Gum & & & \\
\hline OS-G(1:0) & 1 & 0 & 3.30 & 0.00 & 1.56 & 0.20 & 0.98 \\
\hline OS-G(0.75:0.25) & 0.75 & 0.25 & 2.48 & 0.28 & 1.58 & 0.14 & 1.00 \\
\hline OS-G(0.5:0.5) & 0.50 & 0.50 & 1.65 & 0.55 & 1.59 & 0.17 & 1.00 \\
\hline OS-G(0.25:0.75) & 0.25 & 0.75 & 0.83 & 0.83 & 1.51 & 0.20 & 1.00 \\
\hline OS-G(0:1) & 0 & 1 & 0.00 & 1.10 & 1.58 & 0.17 & 0.97 \\
\hline \multicolumn{8}{|c|}{ Plain yoghurt style samples } \\
\hline \multirow[t]{2}{*}{ Abbreviation } & \multicolumn{2}{|c|}{ Volume fraction } & \multicolumn{2}{|c|}{ Conc. $(w / v \%)$} & Hardness & \multirow{2}{*}{\multicolumn{2}{|c|}{$\begin{array}{l}\text { Adhesiveness Cohesiveness } \\
\times 10 \mathrm{~J} / \mathrm{m}^{3}\end{array}$}} \\
\hline & Starch & : Guar gum & Starch & Gum & $\times 10^{2} \mathrm{~N} / \mathrm{m}^{2}$ & & \\
\hline YS-G(1:0) & 1 & 0 & 6.20 & 0.00 & 5.28 & 1.18 & 1.00 \\
\hline YS-G(0.75:0.25) & 0.75 & 0.25 & 4.65 & 0.50 & 5.25 & 1.34 & 0.98 \\
\hline YS-G(0.5:0.5) & 0.50 & 0.50 & 3.10 & 1.00 & 5.36 & 1.48 & 0.99 \\
\hline YS-G(0.25:0.75) & 0.25 & 0.75 & 1.55 & 1.50 & 5.36 & 1.35 & 1.00 \\
\hline$Y S-G(0: 1)$ & 0 & 1 & 0.00 & 2.00 & 5.46 & 1.49 & 1.00 \\
\hline
\end{tabular}




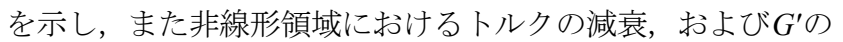
減少も類似し, 他の3種類の試料よりもひずみ依存性は小さく なることが示された.このことより，サラダ油状試料および ヨーグルト状試料, いずれにおいてもデンプン単独試料のひ ずみ依存性が最も大きく，グアーガムの配合割合が増加する に従い, ひず夕依存性は小さくなることが示された. 線形領域

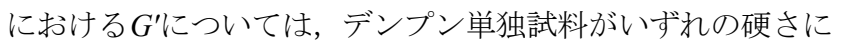
おいても最も高い值を示した. しかし, 混合系試料において, 配合割合と線形領域における $G^{\prime}$ 関係は見いだせなかった。

一方, $\tan \delta$ は, いずれの試料においても線形領域において, デンプン単独試料が他の 4 試料に比べ小さく, グアーガムの 配合割合が多い3種類の試料の $\tan \delta$ は同程度となった。
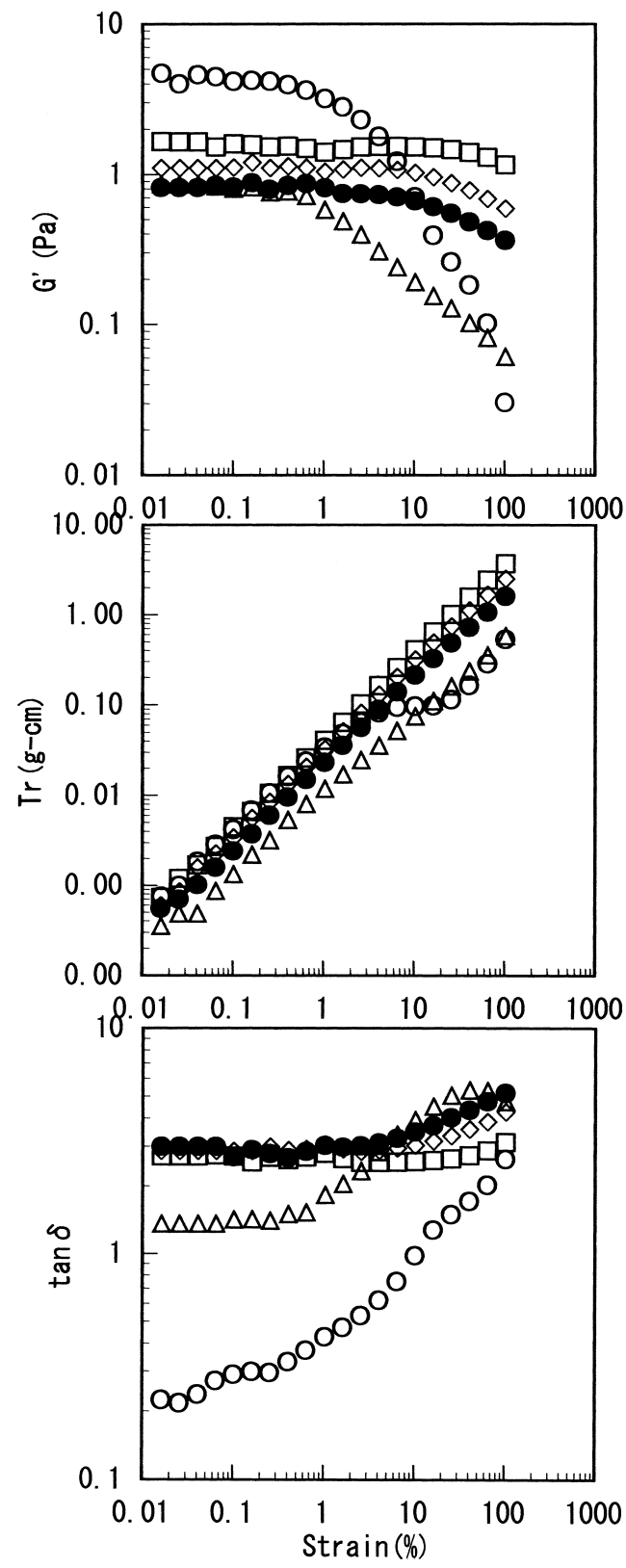

Fig. 1. Strain dependencies of $G^{\prime}, T_{\mathrm{r}}$ and $\tan \delta$ for salad oil style samples $\left(20^{\circ} \mathrm{C}\right)$.

O:OS-G(1:0), $\triangle: \mathrm{OS}-\mathrm{G}(0.75: 0.25), \bullet: \mathrm{OS}-\mathrm{G}(0.5: 0.5)$

$\diamond: \mathrm{OS}-\mathrm{G}(0.25: 0.75), \square: \mathrm{OS}-\mathrm{G}(0: 1)$

\section{2 周波数依存性}

Fig. 3にサラダ油状試料，およびFig. 4 にヨーグルト状試料

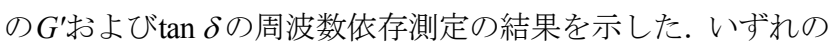
試料においても，低周波数側で， $G^{\prime}$ 試料間の差が大きい.

サラダ油状試料では，低周波数側で OS-G(1:0), 次いで OS-G(0.75:0.25)の順とデンプンの配合割合が多い試料の $G^{\prime}$ で あるほど大きくなっている.一方, OS-G(0.5:0.5), OS-G(0.25:0.75), OS-G(0:1)の $G^{\prime}$ は同程度の值を示し, 周波数依存性も類似して いる. また，いずれの試料も低周波数側では，第二平坦部4) と推測される部分が観察される。第二平坦部はデンプンが形 成する内部構造に起因するものと考えられ，デンプンの配合 割合が多い試料であるほど，デンプンの形成する凝集構造の
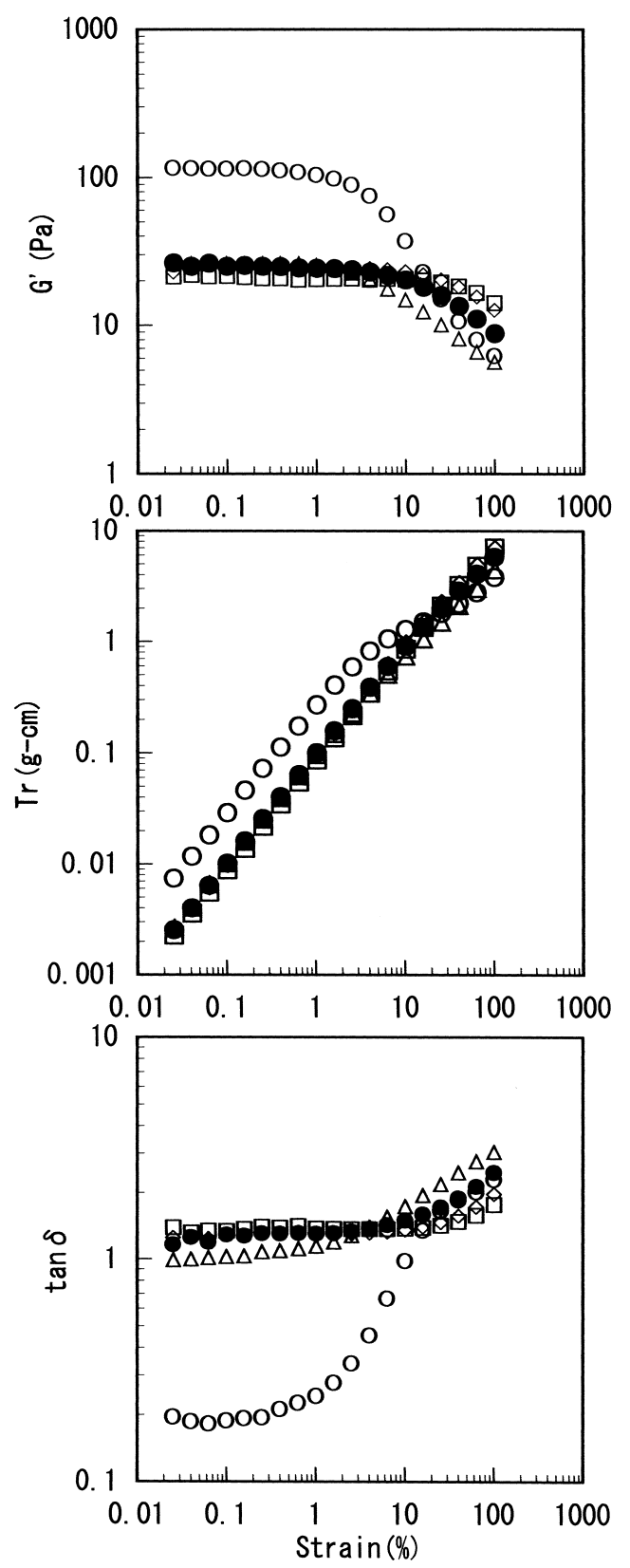

Fig. 2. Strain dependencies of $G^{\prime}, T_{\mathrm{r}}$ and $\tan \delta$ for plain yoghurt style samples $\left(20^{\circ} \mathrm{C}\right)$.

O:YS-G(1:0), $\triangle: Y S-G(0.75: 0.25), \bullet: Y S-G(0.5: 0.5)$, $\diamond: Y S-G(0.25: 0.75), \square: Y S-G(0: 1)$ 
緩和が長時間であることを示している。また，OS-G(0.5:0.5), OS-G(0.25:0.75), OS-G(0:1)の $\tan \delta$ の周波数依存性はほぼ同様 の傾向し, 低周波数側で $\tan \delta$ は増加している. デンプン配合 割合が多いOS-G(0.75:0.25)の $\tan \delta$ は, 高周波数側で OS-G(0.5:0.5), OS-G(0.25:0.75), OS-G(0:1) と同様の值を示して いるが, 周波数が小さくなるに従い異なる傾向を示し, 周波 数依存性も上記の 3 種の試料よりも小さくなっている. また, 測定周波数範囲内のOS-G(1:0)の $\tan \delta$ は, 1 以下を示し, 周波 数依存性は小さい.

ヨーグルト状試料においても, サラダ油状試料と同様，低 周波数側でYS-G(1:0), 次いでYS-G(0.75:0.25), YS-G(0.5:0.5) とデンプンの配合割合が多い試料の $G^{\prime}$ が大きくなっている. また, YS-G(0.25:0.75), YS-G(0:1)の $G^{\prime}$ は同程度の值を示し， 周波数依存性も類似している. YS-G(1:0), YS-G(0.75:0.25), YS-G(0.5:0.5) 試料に低周波数側で, 第二平坦部と推測される 部分が観察される.また, YS-G(0.25:0.75), YS-G(0:1)の $\tan \delta$ の周波数依存性はほぼ同様の傾向し, 低周波数側で $\tan \delta$ は増 加している. YS-G(0.5:0.5), YS-G(0.75:0.25)のtan $\delta$ は, 高周波 数側でYS-G(0.25:0.75), YS-G(0:1) と同様の值を示しているが,
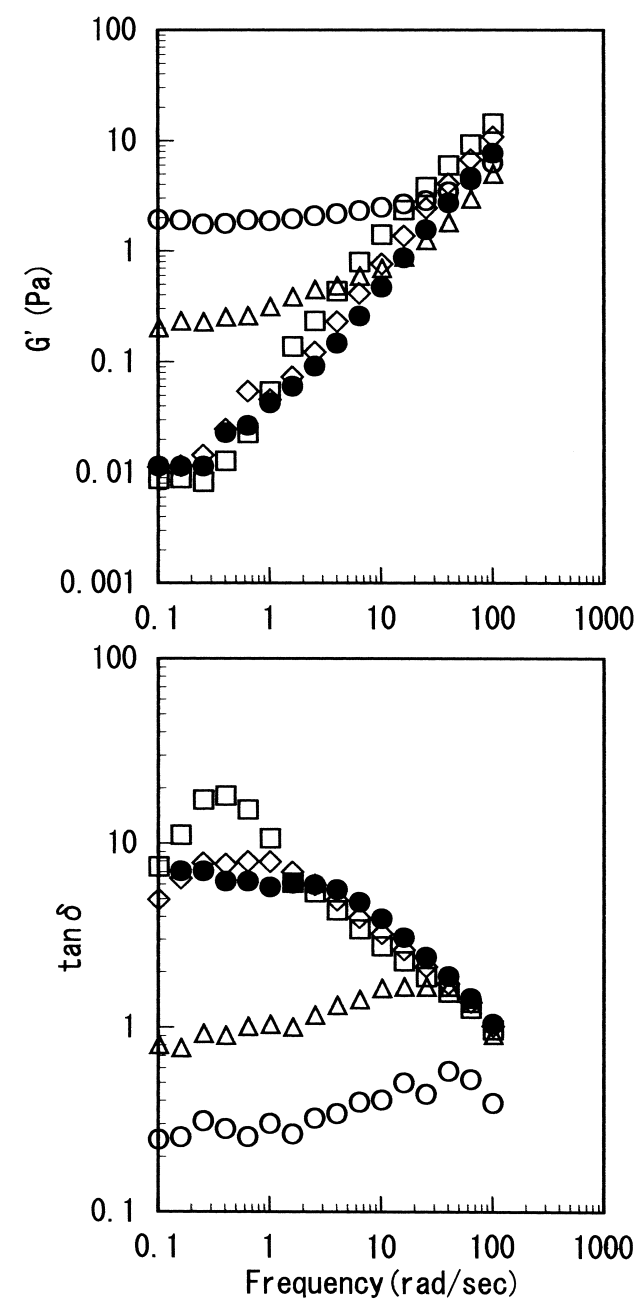

Fig. 3. Frequency dependencies of $G^{\prime}$ and $\tan \delta$ for salad oil style samples $\left(20^{\circ} \mathrm{C}\right)$.

O:OS-G(1:0), $\triangle: \mathrm{OS}-\mathrm{G}(0.75: 0.25), \bullet: \mathrm{OS}-\mathrm{G}(0.5: 0.5)$,

$\diamond: \mathrm{OS}-\mathrm{G}(0.25: 0.75), \square: \mathrm{OS}-\mathrm{G}(0: 1)$
周波数が小さくなるに従い異なる傾向を示し，低周波数側の 周波数依存性は小さい。 また, YS-G(1:0)の $\tan \delta$ は1以下を示 し, 周波数依存性は小さい.

以上の結果より，いずれの試料においても，低周波数側で 試料の特性が顕著に現れ，デンプン配合割合の大きい試料で あるほど低周波数側での $G^{\prime}$ は高く, $\tan \delta$ は小さく, 第二平坦 部が認められ，緩和時間が長いことが示された。 また，サラ ダ油状試料では, OS-G(0.5:0.5), OS-G(0.25:0.75), OS-G(0:1), ヨーグルト状試料では，YS-G(0.25:0.75), YS-G(0:1)の周波数 依存性は類似したものとなった。

\section{3 官 能 評価}

サラダ油状試料の官能評価結果をFig. 5に, またヨーグルト 状試料の官能評価結果をFig. 6に示した.いずれの試料におい ても，デンプンの配合割合が大きい試料であるほど，口中で のべたつき感は少なく，口中の残留感も少なく，また飲み込 みや寸い傾向にあることが示された，その傾向は，軟らかい サラダ油状の混合系試料の方がヨーグルト状試料よりも，多 くの試料間に有意差が認められ，顕著である.
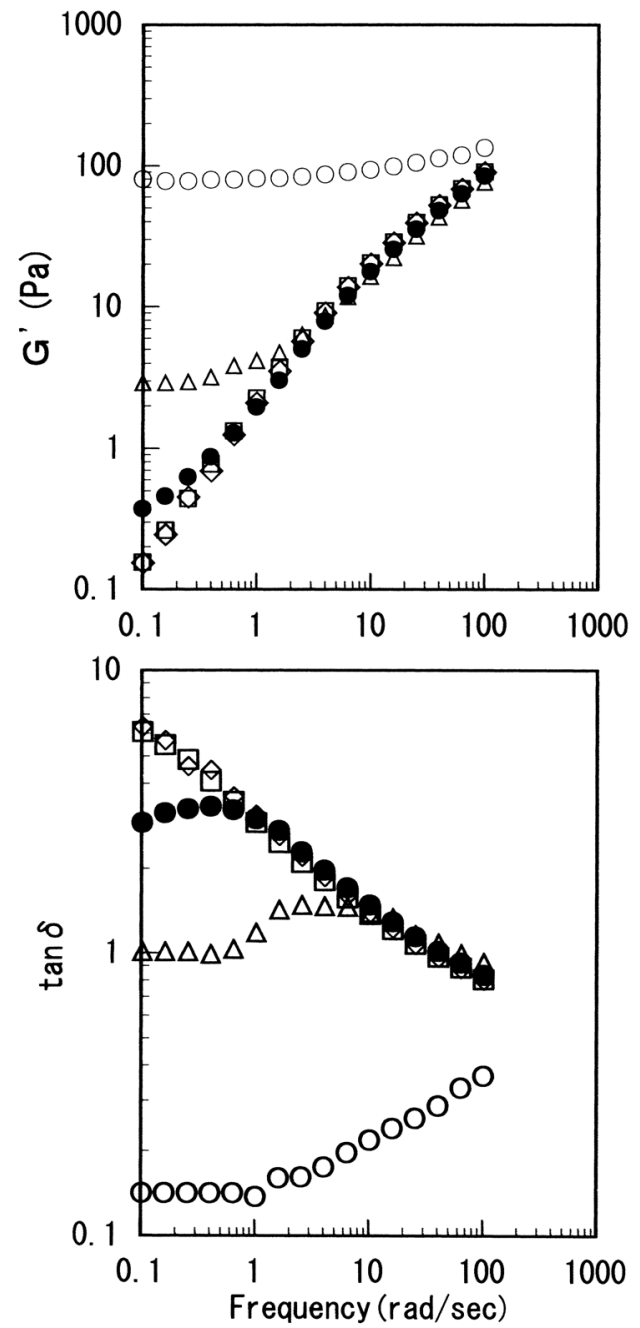

Fig. 4. Frequency dependencies of $G^{\prime}$ and $\tan \delta$ for plain yoghurt style samples $\left(20^{\circ} \mathrm{C}\right)$.

O:YS-G(1:0), $\triangle: Y S-G(0.75: 0.25), \bullet: Y S-G(0.5: 0.5)$, $\diamond: Y S-G(0.25: 0.75), \square: Y S-G(0: 1)$ 


\section{4 動的粘弾性と官能評価}

いずれの硬さにおいても最も口中でべたつかず，残留感も 少なく, また飲み込みやすいと評価されたデンプン単独試料 のトルクおよびG'のひずみ依存性は他の試料に比べて，顕著 に大である.また，試料のひずみ依存性が小さくなるに従い， いずれの硬さにおいても口中のべたつき感, 残留感は増加 し, 飲み込みにくくなる. しかし, 線形領域における $G^{\prime}$ と官 能評価値との間に関係は見いだせなかった。 また, サラダ油 状試料においては, 線形領域における $\tan \delta$ が小さい試料であ るほど, 飲み込みやすいことが示された。 ヨーグルト状試料 においても, 同様の傾向が示されているが, サラダ油状試料 に比べて，その傾向は明確ではなかった.

このことより, サラダ油程度, あるいはヨーグルト程度の 硬さを有する液状食品では, 口中に入れてすぐの口蓋と舌に よる微少なずり変形より得られた弾性と粘性の比, すなわち $\tan \delta$ により口中のべたつき感を評価し, 残留感および飲み込 みや寸さを推測していると考えられる. 続いて, 液状食品は 舌の変形により飲み込みやすい食塊に形成され, 舌の駆動力 により口中から咽頭方向へ移動する.この動作に引き続い て, 喉頭壁後部から食道へ向かっての蠕動運動のによる送り

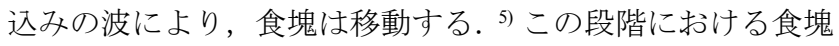
の変形はいずれも, 微少変形ではなく, 大変形に属するもの であると考える. 本研究より, ひずみ依存性, ことに非線形

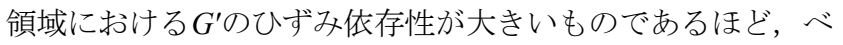
たつかず，残留感も少なく，飲み込み易いという評価が得ら
れた.このことより，小さな力でも変形しやすいために舌の 変形により食塊形成しやすく, また, 蠕動運動によっても変 形しや寸く送り込みやすいため, 飲み込みやすいと評価され たものと推測する.

周波数依存性の測定結果より，低周波数側で試料の特性の 差が現れることを先に述べたが，いずれの硬さにおいても低 周波数側における $G^{\prime}$ が高く, $\tan \delta$ が小さいものほど口中にお けるべたつき感, 残留感も少なく, 飲み込みやすいと評価さ れた．前報5)では弱いゲルのような構造をもつ液状食品は緩 和時間が長いために，咽頭をまとまって通過することより， 飲み込みやすいとの考察を行った。 本研究においても, 低周 波数側の $G^{\prime}$ が高く, $\tan \delta$ が小さく, 緩和時間が長い試料は, まとまって咽頭を通過するとことにより，飲み込みやすいと 評価されたと考えられる.

\section{4. 結 論}

本研究の結果より, サラダ油状やヨーグルト状の粘稠な液 状食品の口中感覚や飲み込みやすさを把握する手段として, 動的粘弾性のひずみ依存測定における線形領域の $\tan \delta$, およ びひずみ依存性，ことに非線形領域におけるトルクと $G^{\prime}$ の減 衰状態を検討することであることが示された．また，周波数 依存測定では，試料の特性をあらわす低周波数側の $G^{\prime}$ および $\tan \delta$ を把握することにより, 飲み込みやすさをある程度, 推 測できると思われる.
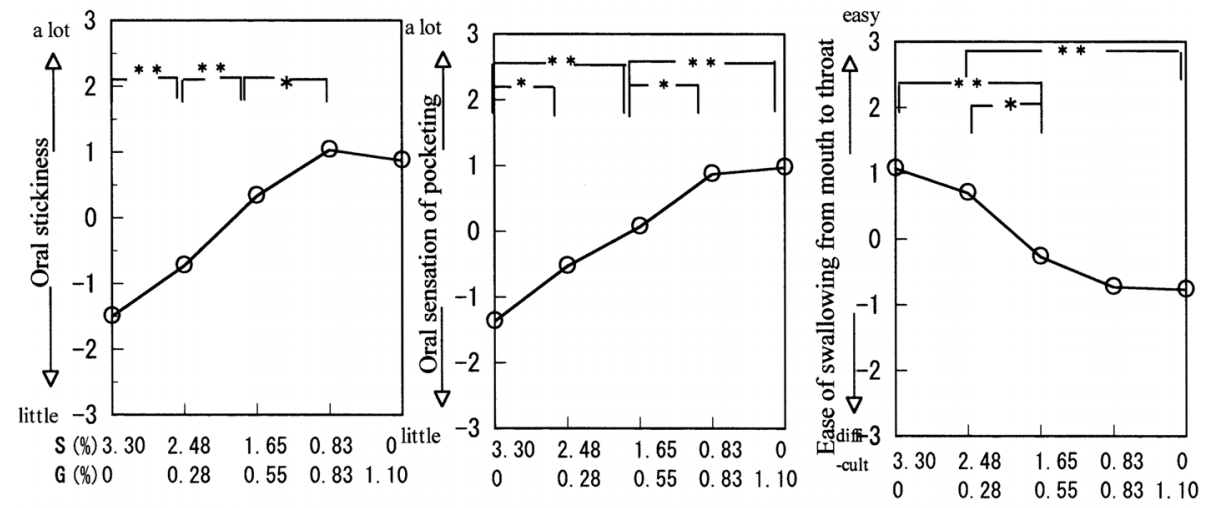

Fig. 5. Sensory evaluation for salad oil style samples $\left(20^{\circ} \mathrm{C}\right)$.
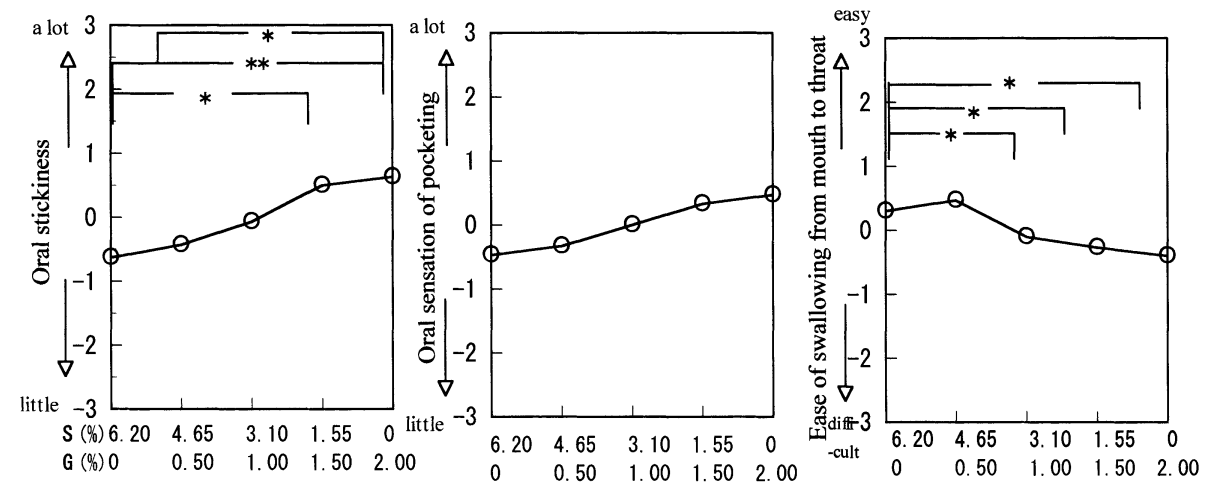

Fig. 6. Sensory evaluation for salad plain yoghurt style samples $\left(20^{\circ} \mathrm{C}\right)$. 
摂食能力が減退した高齢者にとって, むせずに飲み込みや すいの食物の条件として, 口腔や咽頭を通過するときに，変 形しやすいものであることが，食事作りの現場より報告され ている. 67)これは, 主にゲル状食品を対象としたコメントで あると推測されるが, 本研究の結果から, ゾル状食品にも適 応できる条件であると考える。

本研究において, 口中感覚や飲み込みやすさの官能評価值は ずり変形により得られる物性值と関係あると考え, 動的粘弾性 との関係を検討した. 本研究の結果をもとに今後は, 測定条件 を工夫することにより, 簡便に口中感覚および飲み込みやすさ を把握することができる測定方法の開発を試みたい.

\section{REFERENCES}

1) Takahashi T, Ogoshi H, Miyamoto K, and Yao M. L, Nihon Reoroji Gakkaishi, 27, 169, (1999).

2) Takahashi T, Maruyama A, Ogoshi H,The Japanese Journal of Nutrition and Dietetics, 55, 253(1997).

3) Ministry of Health and Welfare in Japan, "The conditions of measurement were based on examinations of the diet criteria for patients with difficulty in masticating or swallowing”, 1994.

4) Onogi S, "Kagakusyanotameno Reoroji”, Kagakudojin, Kyoto, 1986.

5) Groher, M.E., "Dysphagia”, Butterworth Publishers, United States of America, 1984.

6) Seirei Mikatagahara Hospital,"Pocket Manual of Dysphagia”, Ishiyaku Publishers, Inc., Tokyo, 2002.

7) Kaneko Y, Mukai Y, "Sessyoku Engesyogai No Hyokaho To Syokujishido”, Ishiyaku Publishers, Inc., Tokyo, 2001. 